\title{
DIGIPEN: SECONDARY SCHOOL PROJECT-BASED LEARNING IN GAME DESIGN, DIGITAL ARTS AND LIFE SKILLS
}

\author{
Edward Howe \\ Thompson Rivers University \\ Andres Ruberg \\ Kamloops School District
}

\begin{abstract}
This action research investigates DigiPen, an innovative teacher developed secondary school course where students are actively engaged in project-based learning while studying how to work effectively in teams focused on digital game design. Students apply art, math, physics, and computer science knowledge and learn important life skills. DigiPen exemplifies the new British Columbia curriculum with cross-curricular integrated approaches to learning. This mixed-methods study identified five themes: career, life skills, leadership, teamwork, and inclusion. Students indicated DigiPen played a significant role in their higher education choices and career paths. DigiPen shows great promise for providing meaningful project-based learning experiences for students.
\end{abstract}

Keywords: Project-based learning, DigiPen, digital game design, secondary school, cross-curricular pedagogy

\section{INTRODUCTION}

The theory/practice divide still pervades much curriculum, teaching, and learning at all grade levels. While much research supports innovative pedagogies including inquiry and project-based learning (Blumenfeld et al., 1991; Holm, 2011; Jacobs, 2018; MacMath et al., 2017; Pine, 2009; Zeichner, 2001), what goes on in K-12 classrooms often does not reflect these practices, as teachers tend to teach the way they were taught to and resort to traditional teaching strategies (Alexander et al., 2017; Britzman, 2003; Howe, 2017; Korthagen et al., 2006). What can be done to bridge the gap between research and teaching? One solution is to provide action research 
opportunities during initial teacher education, so that teacher educators, teachers, and teacher candidates can effectively build bridges between theory and practice; universities and schools; scholars and practitioners. In particular, project-based learning that incorporates the new British Columbia (BC) curriculum (2020) leads the way (MacMath et al., 2017). Moreover, interdisciplinary action research involving professional learning collaborations between teacher candidates and in-service teachers, shows great promise (Brown et. al, 2018). Thus, in the spirit of building bridges and breaking down educational silos, the Thompson Rivers University / Kamloops School District K-16 Innovation Network was formed in 2016 and has since spawned a number of exciting research projects, involving teams of university faculty, teacher candidates, and school teachers. These partnerships embrace project-based learning and are cross-curricular, reflecting the new BC curriculum core competencies: communication, creative thinking, critical thinking, positive personal and cultural identity, personal awareness and responsibility, and social responsibility. This paper focuses on one such research project — DigiPen.

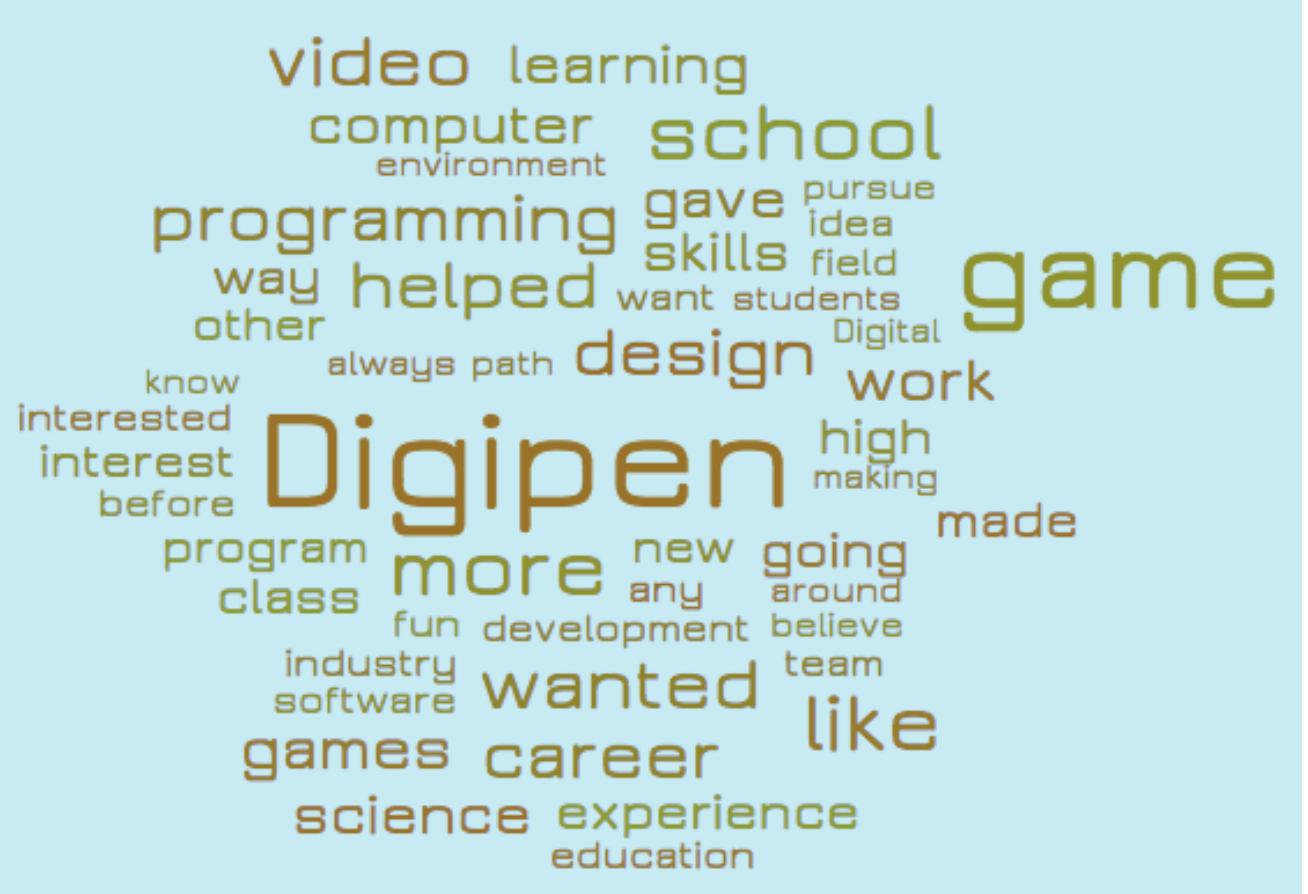

This research highlights collaboration between a secondary Bachelor of Education STEM (Science, Technology, Engineering and Math) program and a unique teacherdeveloped high school course, based on the DigiPen Institute of Technology (DigiPen, 2020; Kushner, 2002). Over the past two decades, DigiPen programs have spread to high schools across North America and around the world. DigiPen is a significant part of the innovative Singapore education hub, Global Schoolhouse (Knight \& Morshidi, 2011). In DigiPen, students are actively engaged in project-based learning while studying how to work effectively in teams focused on digital game design. Students learn how to apply their math, physics, and computer science knowledge to curriculum that is relevant, interesting and fun. In addition, students learn a variety of important life skills such as how to manage complex tasks and work together in small groups over a semester to produce innovative games. DigiPen provides a niche for some students who might not always find school the most appealing learning environment. Moreover, DigiPen exemplifies the new BC curriculum with cross-curricular and integrated 
approaches to learning (British Columbia Ministry of Education, 2020). A few years ago, the Premier of $\mathrm{BC}$ announced that all students from K-12 must learn how to program a computer. This is an admirable goal. However, it is unclear how this can be achieved and teachers are at a loss as to how to modify or revise existing courses in order to effectively deliver this to students (CBC News, 2016). DigiPen is one possible solution, as it represents an effective way to integrate computer programming and animation into a course that connects STEAM subjects (Science, Technology, Engineering, Arts and Math) to actively engage students in meaningful ways.

Research supports gaming and game design as a viable method of learning (Gee, 2005; Shute \& Kim, 2011). In the area of game design, Gee's (2010) working example as a new mode of inquiry shows great promise in providing a context to scaffold peer discussion with the ultimate goal of sharing curriculum, teaching and learning. However, strategies for integrating game design in traditional classrooms are few and far between. Indeed, examples of effective integration of game design in school are rare (Gee, 2010). Nevertheless, a noteworthy exception and working example of game design within a classroom setting was recently reported (Herro, 2015). DigiPen is another exceptional example (there are only two schools offering this course in BC). Thus, with respect to the foregoing, the purpose of this research is to investigate Digital Game Design (DigiPen) project-based learning to see how this unique program affects students' learning, education, and career path. The structure of this paper is as follows: first, we outline our conceptual framework and the methodology used. Then, the DigiPen curriculum is described in detail. Finally, the results of this study are reported, and the implications are discussed.

\section{CONCEPTUAL FRAMEWORK}

The catalyst for this study was my son's career changing DigiPen experience in 20152016 (he is now studying Software Engineering). It was questions from parents at the final presentation of their games (an impressive showcase modeled on similar events in the gaming industry, offering students a Dragon's Den style competition) that prompted me to reach out to the instructor to investigate DigiPen. I saw this as an opportunity to help the school district understand what elements of DigiPen were most successful and how it might be replicated in other courses. Also, this was an opportunity to involve teacher candidates as researchers. It became a pilot for our new Bachelor of Education STEM program, launched in 2018, embedding teacher action research into coursework and the long practicum.

This research stems from shared interests in science and constructivist educational philosophies between the principal researcher (PI), Edward Howe, and the DigiPen teacher, Andres Ruberg. We believe that effective teaching and scholarly research are essential elements of teaching and learning across the K-16 curriculum. So, we are both scholar practitioners - teachers and researchers - and as such, our shared conceptual framework reflects the tenets of action research, project-based and inquiry learning. DigiPen exemplifies project-based approaches to curriculum, teaching and learning and is well described by the following definition:

Project-based learning can be described as student-centered instruction that occurs over an extended time period, during which students select, plan, investigate and produce a product, presentation or performance that answers a

The Canadian Journal of Action Research. Volume, 20, Issue 2 (2020), 28-47. 
real-world question or responds to an authentic challenge. Teachers generally serve as facilitators, providing scaffolding, guidance and strategic instruction as the process unfolds. (Holm, 2011, p. 1)

Project-based learning has its roots in real world experience and Dewey's (1938) constructivist philosophy - education is meaningful reflection on experience. It also draws from a growing body of literature on situated learning (Hung, 2002; Korthagen, 2017; Lave \& Wenger, 1991; Vincini, 2003). In addition, developments in cognitive psychology and learning theory have extended our knowledge of metacognitive processes and educational psychology (Brown et al., 1989; Cole, 1996). Indeed, there is much research to support the premise that we learn through active participation and experience (Clandinin \& Connelly, 2000; Falkenberg, 2015; Howe, 2017). Clearly, there is consensus among educators that knowledge, thinking, and doing are inextricably linked. We know that learning builds on prior experiences. Moreover, learning is a coconstruction of knowledge amongst learners and teachers. Project-based learning embodies all the aforementioned and is a significant untapped resource in our design of $\mathrm{K}-16$ curriculum, teaching, and learning.

\section{INITIAL TEACHER EDUCATION AND ACTION RESEARCH}

The complex and contested area of teacher education is filled with dilemmas (Falkenberg, 2015; Loughran et al., 2004; Martin \& Russell, 2009). How can teacher educators effectively bridge gaps between theory and practice; universities and schools; scholars and practitioners? As this research stems from a joint initiative between a university and school district, with the goal of improving learning for students at both levels, it is a form of action research (Tomal, 2010). In action research, participants identify a problem and act to resolve it. Moreover, action research is conducted with research participants rather than on participants (O'Brien, 1998). Teachers can play a major role in the design of classroom research, data collection and interpretation (Pine, 2009; Zeichner, 2001).

Hence, the research questions were generated collaboratively between the PI and the DigiPen teacher. Furthermore, this action research project arose from key stakeholders within the community who expressed a strong desire to find out how this popular program was affecting the career paths of students. This greatly influenced the original design of the study, the survey and the overall conceptual framework of this project. Thus, survey research combined with a blend of narrative inquiry (Clandinin \& Connelly, 2000; Howe, 2010; Xu \& Connelly, 2009) and reflexive ethnography (Fetterman, 1989; Hammersley \& Atkinson, 1983/1989; Wolcott, 1999) were employed (see also: Adler, 2011; Kearns, 2012).

\section{METHODOLOGY}

This study incorporated converging mixed methods design. Reported here are the results of an online survey and narrative inquiry of two teacher candidates. In the first year of this study, in fall 2016, having received ethical approval from our university, the PI recruited a teacher candidate, Sara, as a research assistant (RA). In 2017, another teacher candidate, Michelle, was recruited as an RA. Each RA visited the DigiPen classroom weekly and wrote detailed reflections in an e-journal. These reflections were shared with the PI via email and in-person bi-weekly meetings. Then, the RAs and the PI worked together to make meaning from the journal reflections. Thus, the narrative 
portion of the research text evolved from our teacher-to-teacher conversations (Howe, 2010; Yonemura, 1982). Reflective debriefings and qualitative data from surveys were coded using open and axial coding techniques and crosschecked by the PI, DigiPen teacher and RAs. Through iterative coding and constant comparison, codes were collapsed and synthesized into major themes (Creswell \& Creswell, 2018).

Existing and former DigiPen students were contacted via email and invited to participate in an online survey using Survey Monkey (see Appendix 1). With the help of two DigiPen teachers (the co-author and a former teacher), this online survey was sent out to all DigiPen graduates from 4 cohorts (fall 2012- fall 2016). Of the 71 students contacted, 29 responded. The surveys included demographics and 5-point Likert-scale questions, as well as open-ended questions pertaining to how DigiPen affected students' program of study and career paths. Some DigiPen students were also interviewed informally during class by RAs and so interpretive data was collected from the classroom setting. Thus, data sources included surveys of former graduates and ethnographic data from the DigiPen classroom. In addition, current DigiPen students provided formative feedback to their teacher on a weekly basis online using Google Docs. Also, RAs made weekly observations and journal reflections of the DigiPen classroom, collecting documents, videos, photographs (see Appendix 2), and observations over the course of the semester. Space does not permit detailed reflections from both RAs, but a vignette from one RA's narrative is included at the end of the results section, following the survey results. First, we present a description of the DigiPen curriculum.

\section{DIGIPEN CURRICULUM DESIGN AND IMPLEMENTATION}

Here, we describe the DigiPen course in detail. First, the contents are highlighted and then the pedagogy and rationale are summarized. In DigiPen, students learn computer programming, digital art, game design, math, physics and other cross-curricular skills. DigiPen is an intense course that runs all day, every day, with one teacher, for an entire semester (450 hours), in a close cohort. Students earn 16 credits towards high school graduation while also receiving advance credits towards up to two university courses.

\section{Curriculum Areas}

DigiPen, while focusing on digital game design, is cross-disciplinary, integrating a number of subjects including computer science, art, math and physics. In addition, students are introduced to relevant and highly sought after job skills such as working in teams and problem solving through project-based learning. The DigiPen curriculum areas are summarized here:

Computer Programming

- Learn general concepts in Computer Science in the context of Java programming language

- Use Java-based game engine code library to create more complex programs

- Learn Javascript-like scripting language within the context of a game engine

Digital Art

- Learn fundamental art and animation theory

- Create 2-dimensional digital art projects, both static and animated

- Learn how to create and animate in 3D

The Canadian Journal of Action Research. Volume, 20, Issue 2 (2020), 28-47. 
Game Design

- Learn game design fundamentals through board games

- Explore game design processes by which complete and logically consistent games are created

- Analyze games from a design perspective and present findings in a presentation format

Math \& Physics

- Apply concepts from linear algebra to vector manipulation

- Learn coordinate-based algebra and trigonometry

- Learn vector-based kinematics and dynamics

Team Management

- Build capacity to work as a team through small group projects with randomly assigned groups

- Equip students with team management resources and conflict resolution skills

\section{DigiPen Pedagogy}

A wide variety of evidence points to the value of engaging students with content through the use of examples and projects that they find personally relevant and interesting. The model used in the DigiPen classroom comprises a high school student cohort simultaneously studying four courses within the context of a theme in which they have expressed a personal interest. These students work with the same peers all day every day for one semester learning material in a context that they find personally meaningful. Alongside this model, passionate instruction seems to increase student engagement, resilience and willingness to take risks, all of which contribute to deeper and more significant levels of understanding.

\section{Interdisciplinary Theme-Inspired Project-Based Curriculum}

We have found that students generally learn best when they are solving problems and working on projects that they believe have relevance to their interests and potential futures. The challenge with traditional classrooms is that each student has different interests and ideas of what their future holds. This means that classroom teachers can try to make projects that appeal to individual student interests, but it is difficult, and is rarely achieved on a regular basis. By grouping a cohort of students according to their common interest in a theme or topic, the challenge in making projects relevant disappears. The opportunities for relevance expand even further when one considers that these students are being taught four courses simultaneously within the context of their chosen theme. This means that projects can seamlessly include material from a wide variety of subjects and has the added benefit of having projects that meet curricular goals for several courses simultaneously. Based on our experience, students who believe that what they are doing matters can achieve incredible results, far beyond what they could generate with a generic assignment in a traditional classroom.

\section{Growth Mindset}

There is a large volume of research and anecdotal evidence pointing out the advantages associated with developing a growth mindset in students. Students should regularly have discussions with their teacher to ensure that they are moving towards a belief that 
their strengths and abilities are not fixed. The concept of developing a "growth mindset" in students has existed for decades, and recent neurological research has confirmed that having a growth mindset may be the largest predictor of student success during their secondary education and beyond (Dweck, 2006). This philosophy, more than any other perhaps, will result in capable students and successful project-based learning outcomes.

\section{Community Building}

Almost every day, for up to half the class time, students work in randomized groups, and share their findings with peers. Seeing one of the largest benefits of working with the same 28 people every day requires students develop a strong sense of community and remain open to collaboration. Regularly working with different students in the class and then sharing findings as a group has numerous benefits. This teaching strategy encourages building relationships with everyone in the class, not just those an individual may relate to best or those with whom they generally agree. Randomized groups allow students to develop new perspectives and approaches to problems in addition to building their capacity to share ideas and express opinions. Ultimately, this structure builds a classroom in which ideas flow naturally between students, resulting in a shared knowledge to which the entire class has access. This is the goal of many organizations and reflects a society in which every individual has value. Moreover, this classroom structure mirrors that of most workplaces.

Beyond the building of community, students grow immensely in confidence and presentation ability. This occurs because in addition to presenting and defending ideas within their small groups, student groups share their results with the class on a regular basis. To summarize, the small group work encourages students to work with a variety of individuals, promoting the building of an interdependent community of learners and building student confidence to share their understanding with others.

\section{ASSESSMENT ELEMENTS}

\section{Skills-Based Assessment}

Students are assessed on skills only in the DigiPen classroom. There is no traditional "mark" as such and thereby no homework component, test component, or other traditional components associated with traditional grading schemes. Students do have occasional assignments, tests, and other traditional activities interspersed between instruction and projects, but these serve only as opportunities to build and display specific skills. When a student completes this academy, they have a list of skills developed over the course of the semester, with a proficiency level highlighted for each skill and a description of what specific tasks they should be able to complete based on that proficiency level. These skills are developed over the course of the entire semester and as a result a student's level of ability is constantly changing and their current skill assessment reflects their current level of understanding (not an average).

\section{Project-Based Learning}

The majority of the work that students do in this setting is projects that are either designed to help students develop specific skills or open-ended in the sense that students can choose which skills they plan to develop and display within the project deliverables. Although there is some traditional delivery before major project work can begin, the vast majority of student learning occurs during the project itself. The lessons 
taught prior to starting a project are more a means of showing what is possible and how to find and use resources. Students generally push themselves far beyond what is "taught" and have created projects that challenge or extend the built-in limitations of the software they are using. During project work time, the teacher is available for assistance, but rarely "solves" a student's problem. Most of the time students are directed to a resource (the material covered, past projects or most often another student who has solved a similar problem). When the teacher does assist a student directly it is understood that they are now the "expert" on that problem and that other students encountering similar challenges will be sent to them.

\section{Student Self- and Peer-Assessment}

At the end of a project, students are given a self-assessment sheet, where they describe what they accomplished, challenges they overcame and what level they believe themselves to be at with the specific skills they were trying to display with that project. For each self-assessed skill, students are required to give a specific piece of evidence that speaks to the tasks that they should be able to perform at the indicated level of proficiency. Additionally, most major projects also involve some form of peerassessment where two or three other students will look at the project. In this confidential peer assessment, students give each other feedback as to what they were impressed with, what they would improve and at what level they would currently assign their peer in the specific skills on display. The DigiPen teacher collates the selfassessment, peer-assessment and teacher-assessment in order to provide a holistic final report enabling the student to respond in a post-production reflection process following each major project.

With our conceptual framework articulated and the DigiPen curriculum and educational philosophy explained, we now turn our attention to the results of the study.

\section{RESULTS}

What follows is a summary of the surveys, ethnographic field data and reflections from September 2016 through May 2017. The survey responses helped to frame subsequent conversations in order to probe deeper into students' experiences. In particular, the focus was on how DigiPen affected higher education and career choices. Five significant themes emerged: Career, Skills, Leadership, Teamwork and Inclusion as seen in Table 1.

\section{Career}

There is a strong connection between the DigiPen program of instruction in digital game design and the decision of many students to pursue higher education in various related fields such as software design and animation. While career opportunities utilizing computer programming and software engineering abound, very few courses are available to high school students, making DigiPen unique in this regard. Interest in DigiPen continues to grow as more students in our region discover this program. There were 38 applicants for only 28 seats in the fall 2017 DigiPen class. Students have a keen interest in this field of study. Many of them chose to travel a great distance in order take this course. In fact, some students had to transfer out of their high schools while some had to even arrange for homestays for the semester in order to attend DigiPen. The majority of graduates indicated that DigiPen positively affected their career path (45\% Strongly Agree; 35\% Agree; 20\% Undecided) as shown in Figure 1 and in the following responses to the open-ended questions: 
Table 1

Summary of DigiPen Student Survey Open-Ended Questions

\begin{tabular}{|c|c|c|}
\hline Theme & Tally & Representative Student Responses \\
\hline \multirow[t]{5}{*}{ Skills } & 46 & $\begin{array}{l}\text { I had past experiences with Digital art, Game design, and 3D } \\
\text { modeling. DigiPen [taught] me to fundamentally use all of these } \\
\text { skills together. (SS4) }\end{array}$ \\
\hline & & $\begin{array}{l}\text { It gave me an abundance of skills and outlooks, as well as } \\
\text { developing my [...] thinking in a new way. (SS1) }\end{array}$ \\
\hline & & It helped my skills in game design to blossom. (NS4) \\
\hline & & $\begin{array}{l}\text { DigiPen, unlike any other class in secondary school, places the } \\
\text { students with little controlled work and [...] taught us to be } \\
\text { involved in our own goals and projects." (SS4) }\end{array}$ \\
\hline & & $\begin{array}{l}\text { DigiPen not only gave me the skills I needed to enter into this } \\
\text { industry, but showed me how the companies (such as we visited) } \\
\text { need to work in a team-based environment. (VS1) }\end{array}$ \\
\hline \multirow[t]{5}{*}{ Career } & 26 & $\begin{array}{l}\text { It opened my eyes to computer sciences and game design... pushed } \\
\text { me to further explore jobs in computer science and confirmed that } \\
\text { I wanted to work in computer sciences. (SS3) }\end{array}$ \\
\hline & & $\begin{array}{l}\text { Before DigiPen I had no idea what I wanted to do for a career. But } \\
\text { now that I've had a taste, I know the video game industry would be } \\
\text { a career I would be happy in. (VS1) }\end{array}$ \\
\hline & & $\begin{array}{l}\text { DigiPen was what led me into the Digital media industry and } \\
\text { helped me understand myself. (SS4) }\end{array}$ \\
\hline & & $\begin{array}{l}\text { It made the idea of being an artist in this line of work more } \\
\text { achievable. (SK2) }\end{array}$ \\
\hline & & $\begin{array}{l}\text { It changed my future dream of being a Mechanical Engineer to a } \\
\text { Software Engineer. (SS9) }\end{array}$ \\
\hline Inclusion & 7 & $\begin{array}{l}\text { I felt like I actually belonged there when normally I felt like an } \\
\text { outcast. (VS1) }\end{array}$ \\
\hline \multirow[t]{3}{*}{ Teamwork } & 5 & It helped me [learn to] work as a team and enjoy learning. (SS1) \\
\hline & & $\begin{array}{l}\text { It was a class full of people who wanted to be there and shared } \\
\text { similar interests. (NS2) }\end{array}$ \\
\hline & & $\begin{array}{l}\text { Before DigiPen I had troubles fitting in... Our class became a close } \\
\text { group of friends and a team. We still help each other out if we're } \\
\text { doing individual projects to do with coding or video games. (VS1) }\end{array}$ \\
\hline \multirow[t]{3}{*}{ Leadership } & 3 & $\begin{array}{l}\text { It helped me learn to be a true leader in a team setting and how to } \\
\text { work in a team without going off on my own. (NS4) }\end{array}$ \\
\hline & & It showed me to look at the whole picture. (LL1) \\
\hline & & $\begin{array}{l}\text { DigiPen treated us like adults, and we had to act [like ones]. With } \\
\text { schools being such a controlling environment, DigiPen gave us the } \\
\text { responsibility. (SS4) }\end{array}$ \\
\hline
\end{tabular}


- It opened my eyes to computer sciences and game design... pushed me to further explore jobs in computer science and confirmed that I wanted to work in computer sciences. (SS3)

- Before DigiPen I had no idea what I wanted to do for a career. But now that I've had a taste, I know the video game industry would be a career I would be happy in. (VS1)

- DigiPen was what led me into the Digital media industry and helped me understand myself. (SS4)

- It made the idea of being an artist in this line of work more achievable. (SK2)

- It changed my future dream of being a Mechanical Engineer to a Software Engineer. (SS9)

\section{DigiPen positively affected my career path}

" Strongly agree " Agree = Undecided

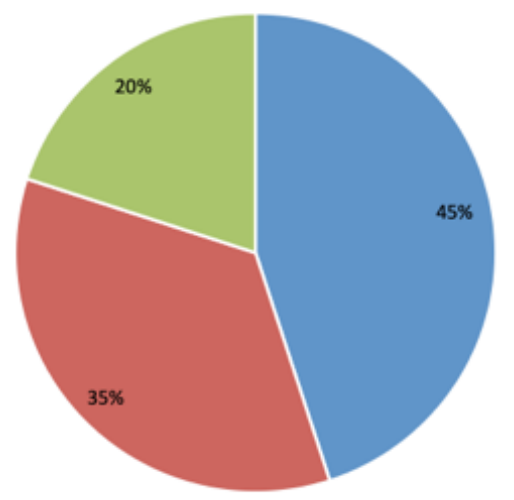

Figure 1: DigiPen and Career Path

Clearly there is strong correlation between DigiPen project-based learning and students' higher education and career paths. This is further illustrated in Figure 2 and the survey responses.

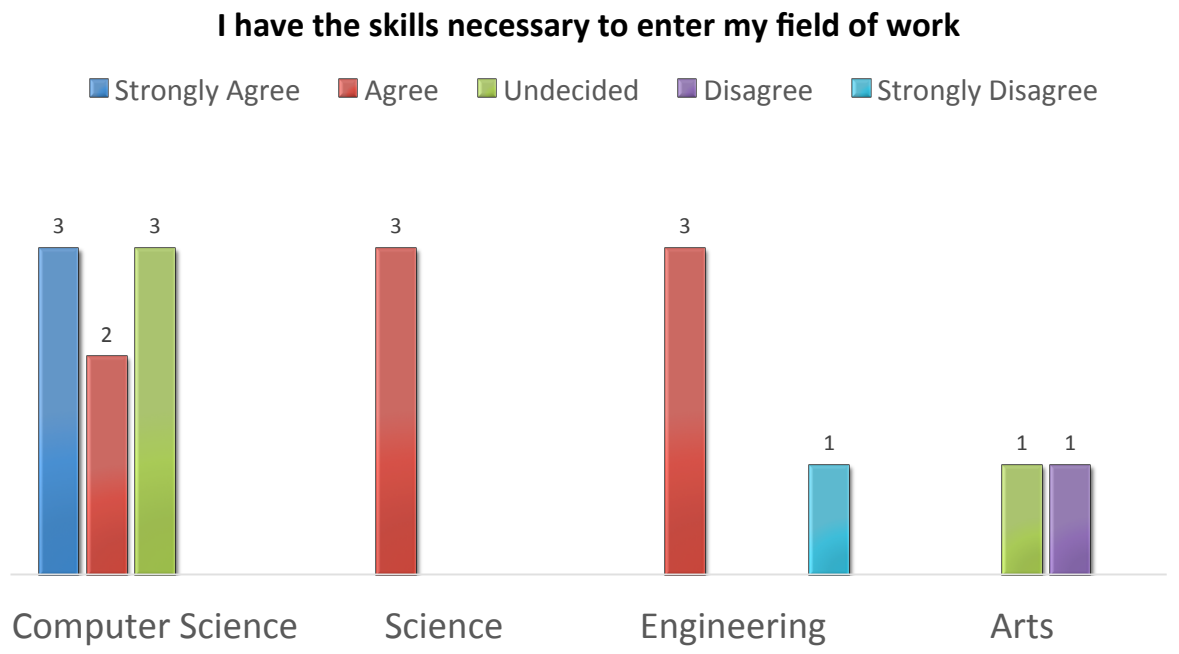

Figure 2: DigiPen and Career Skills

The Canadian Journal of Action Research. Volume, 20, Issue 2 (2020), 28-47. 


\section{Skills: I have the Skills Necessary to Enter my Field of Work}

Many students attested to the unique skills they acquired during the DigiPen course. The following quotes describe specific skills such as computer programming, physics and math, and how these skills were effectively integrated throughout the semester.

- I had past experiences with Digital art, Game design, and 3D modeling. DigiPen [taught] me to fundamentally use all of these skills together. (SS4)

- It gave me an abundance of skills and outlooks, as well as developing my [...] thinking in a new way. (SS1)

- It helped my skills in game design to blossom. (NS4)

- DigiPen, unlike any other class in secondary school, places the students with little controlled work and [...] taught us to be involved in our own goals and projects. (SS4)

- DigiPen not only gave me the skills I needed to enter into this industry, but showed me how the companies (such as we visited) need to work in a teambased environment. (VS1)

\section{Leadership}

Another theme strongly endorsed by most students surveyed was leadership. As shown in Figure 3, DigiPen provided leadership skills (38\% Strongly Agree; 52\% Agree; 10\% undecided) to students who otherwise might not have opportunities in other classes to act as leaders. This is further supported by participants' responses to the open-ended survey questions, "How did DigiPen affect your learning?" and "Do you have anything else to share?"

- It helped me learn to be a true leader in a team setting and how to work in a team without going off on my own. (NS4)

- It showed me to look at the whole picture. (LL1)

- DigiPen treated us like adults, and we had to act [like ones]. With schools being such a controlling environment, DigiPen gave us the responsibility. (SS4)

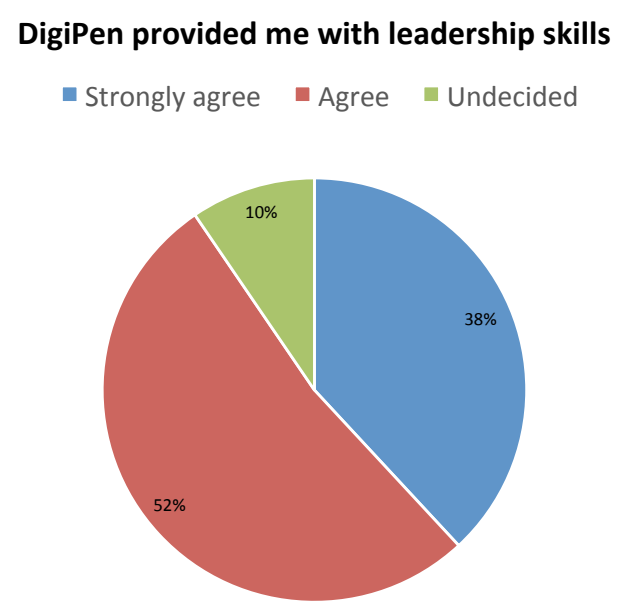

Figure 3: DigiPen and Leadership Skills

\section{Teamwork: DigiPen Helped me Learn how to Work in a Team}

Perhaps one of the most striking and noteworthy features of DigiPen is that many students acknowledged that they are introverted, yet this classroom environment 
encouraged them to develop social skills, to improve their communication with others and to work collaboratively on projects. A majority of participants mentioned the value of learning how to effectively work together as a team to achieve common goals. More than $80 \%$ of participants agreed that DigiPen helped them to learn how to work in a team (62\% Strongly Agree; 24\% Agree; 14\% Undecided) as shown in Figure 4. Responses to open-ended survey questions further support this finding:

- It helped me [learn to] work as a team and enjoy learning. (SS1)

- It was a class full of people who wanted to be there and shared similar interests. (NS2)

- Before DigiPen I had troubles fitting in... Our class became a close group of friends and a team. We still help each other out if we're doing individual projects to do with coding or video games. (VS1)

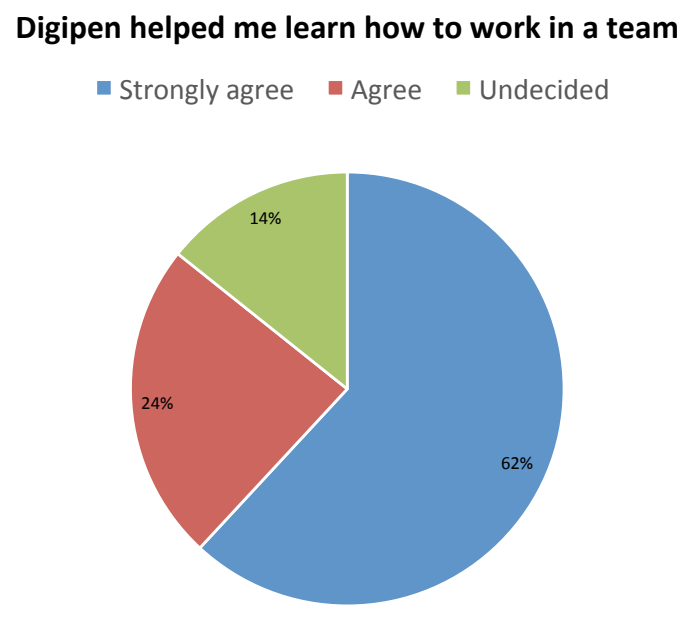

Figure 4: DigiPen and Teamwork

\section{Inclusion and Accomplishment}

In DigiPen, students spend an entire semester together in a cohort. There is a very close bond that forms between them. This was evident through weekly visits to the DigiPen classroom. Students spent the entire day working on their DigiPen projects and often were there late after class as well. Observations made by RAs of the classroom environment included a high level of student engagement, pride and dedication. The following observations were made by Sara, one of the teacher candidates:

- Students were focused, motivated and involved in their project because it was something they were interested in and passionate about.

- Students demonstrated curiosity, cooperation and collaboration.

- Students shared a sense of pride and accomplishment.

The DigiPen classroom gave students a safe, comfortable place to hang out and provided a niche for them. Students made use of couches, video games, and they brought electronic devices like laptops to class, without having to worry about personal items being stolen. Many students did not even use their lockers. DigiPen was a place where they felt part of a group. It provided students with a sense of self-worth and belonging something that had been missing from their previous schooling. "I felt like I actually belonged there when normally I felt like an outcast." (VS1) 


\section{SARA'S NARRATIVE INQUIRY}

My name is Sara Spada and I am a Bachelor of Education student. I have been part of the DigiPen research project since December 2016. Since then, I have made weekly observations at Z Secondary School's DigiPen classroom. I observed students work both independently and in groups of three. In this time, I have learned and witnessed how interactive and purposeful this program is to students.

In being a teacher candidate, we are taught about how important it is to have your students engaged in the materials and lessons in your classroom. We are also taught about how important it is to have the opportunity for inquiry in your lessons and how important it is for students to have ownership in their learning. This is exactly what I observed in the DigiPen classroom. Students were focused, motivated and involved in their project because it was something they were interested in and passionate about. Students were also given the freedom of choice regarding the content they created. The level of creativity that these students presented was astounding; from character development, story plot, to illustrations.

In observing the DigiPen classroom, I saw students generate a lot of curiosity towards their projects. I often heard students discuss among each other "I wonder what would happen if I did this?" or "I wonder if I changed this if it would make my graphics more effective?" This also leads into the concept of cooperation and collaboration. Even though students were presenting their final group projects to be judged by a panel, I never saw students get competitive between groups. Often, students from different groups would work together if someone had a question or problem. I often saw students ask each other for help and gladly work together to solve the problem. From this, I can honestly say that the DigiPen classroom was very much a community for these students. When working in groups of three, students were not allowed to take ideas from their own individual projects and incorporate them into the team game. This way, there had to be a discussion formed among the team members regarding what direction they wanted to take their game in. This very much led students to practice their communication skills, as they had to voice their opinion to their team mates and provide a rationale as to why they thought this idea would serve best.

Students shared a sense of pride and accomplishment when I asked them questions regarding the premise of their game and what role each of them had in their team. When asking students about their journey in the DigiPen program, students often shared how they overcame a concept they initially struggled with, for example with coding and graphics. This very much shows the attribute of selfdiscovery; students were challenged with something and overcame this obstacle.

From my observations, the DigiPen program is very much a gateway for students to pursue further education in digital animation and interactive games. DigiPen is a hands-on and minds-on program. Students are both engaged and challenged throughout the course of this program. The projects throughout this program incorporate not only the core competencies of the BC education plan, but also supports students learning in a way that is both authentic and empowering. 


\section{CONCLUSION}

This research investigated the DigiPen program in order to answer questions such as: How did DigiPen affect students' career paths? Also, during this process, teacher candidates gained valuable experience as research assistants. It is expected this research will help inform future action research and project-based learning involving teacher educators, teachers and teacher candidates. Thus, this research benefits teacher candidates, our program, and the school district. Results show that the teacher candidates made a strong connection between teaching and research. Furthermore, DigiPen graduates indicated that project-based learning played a significant role in their experience and education.

Knowledge is a narrative construct, which references the totality of a person's personal practical knowledge gained from formal and informal educational experience (Xu \& Connelly, 2009). Naturally, teachers have a great deal of experience to draw upon. Much of this is tacit knowledge that often goes unreported but it is an integral part of a teacher's curriculum, teaching and learning. Thus, the educational significance of this study includes the DigiPen program of instruction, in addition to a unique collaborative research methodology. This research is different from many other studies as it employs teacher candidates as undergraduate research assistants. Finally, this research project facilitated knowledge mobilization through the growth and development of the principal investigator, two teacher candidates, and secondary DigiPen teacher to help bridge the gaps between theory and practice; universities and schools; scholars and practitioners. Perhaps most importantly, this research also helps break down the traditional silos of various disciplines to show teacher educators what is possible when we work in collaboration with other key stakeholders in education.

\section{REFERENCES}

Adler, S. M. (2011). Teacher epistemology and collective narratives: Interrogating teaching and diversity. Teaching and Teacher Education, 27, 609-618.

Alexander, R., Britzman, D., Prestage, S., \& Perks, P. (2017). Learning through pedagogies in teacher education. In D.J. Clandinin \& J. Husu, The SAGE handbook of research on teacher education (Vol. 2, pp. 509-512). London: SAGE Publications Ltd. doi: 10.4135/9781529716627

Blumenfeld, P. C., Soloway, E., Marx, R. W., Krajcik, J. S., Guzdial, M., \& Palinscsar, A. (1991). Motivating project-based learning: Sustaining the doing, supporting and learning. Educational Psychologist, 26(3-4), 369-398. doi: 10.1080/00461520.1991.9653139

British Columbia Ministry of Education. (2020). Building student success: BC's new curriculum. https://curriculum.gov.bc.ca/ 
Britzman, D. P. (2003). Practice makes practice: A critical study of learning to teach. Albany: State University of New York Press.

Brown, B., Hartwell, A., \& Thomas, C. (2018). Interdisciplinary design teams of preservice and in-service teachers: Issues with collaboration. Canadian Journal of Action Research, 19(1), 3-21.

Brown, J. S., Collins, A., \& Duguid, P. (1989). Situated cognition and the culture of learning. Educational Researcher, 18(1), 32-42.

CBC News. (2016, September 28). Christy Clark's plan to teach coding to kids flawed says educator. CBC/Radio-Canada. Retreived from http://www.cbc.ca/news/ canada /british-columbia/kids-coding-not-ready-1.3412909

Clandinin, D. J., \& Connelly, F. M. (2000). Narrative inquiry: Experience and story in qualitative research. San Francisco: Jossey-Bass.

Cole, M. (1996). Cultural psychology: A once and future discipline. Cambridge, MA: The Belknap Press of Harvard University Press.

Creswell, J. W., \& Creswell, J. D. (2018). Research design: Qualitative, quantitative and mixed methods approaches ( $5^{\text {th }}$ ed.). Los Angeles: Sage.

Dewey, J. (1938). Experience and education. New York: Collier books.

Dweck, C. (2006). Mindsets: The new psychology of success. New York: Random House.

DigiPen. (2020). https://digipen.edu

Falkenberg, T. (Ed.). (2015). Handbook of Canadian research in initial teacher education (Vol. 6). Ottawa, Canada: Canadian Association of Teacher Educators.

Fetterman, D. M. (1989). Ethnography: Step by step (Vol. 17). Newbury Park, CA: Sage.

Gee, J. P. (2005). Learning by design: Good video games as learning machines. ELearning and Digial Media, 2(1), 5-16. https://doi.org/10.2304/elea.2005.2.1.5

Gee, J. P. (2010). New digital media and learning as an emerging area and "worked examples" as one way forward. Cambridge, MA: MIT Press.

Hammersley, M., \& Atkinson, P. (1983/1989). Ethnography, principles in practice. New York: Routledge.

Herro, D. C. (2015). Implementing game design in school: A worked example. Canadian Journal of Learning and Technology, 41(2). http://dx.doi.org/10.21432/T26G7B

Holm, M. (2011). Project-based instruction: A review of the literature on effectiveness in prekindergarten through 12 th grade classrooms. InSight: Rivier Academic Journal, 7(2), 1. 
Howe, E. R. (2010). A comparative ethnographic narrative approach to studying teacher acculturation. In V. L. Masemann \& S. Majhanovich (Eds.), Papers in memory of David N. Wilson: Clamouring for a better world (pp. 121-136). Rotterdam: Sense Publishers.

Howe, E. R. (2017). Experience, education and story: A transcultural teacher narrative. In M. Etherington (Ed.), What teachers need to know: Topics of inclusion (pp. 272285). Oregon: Wipf and Stock.

Hung, D. (2002). Situated cognition and problem-based learning: Implications for learning and instruction with technology. Journal of Interactive Learning Research, 13(4), 393-414.

Jacobs, S. D. (2018). A history and analysis of the evolution of action and participatory action research, Canadian Journal of Action Research, 19(3), 34-52.

Kearns, S. (2012). Seeking researcher identity through the co-construction and representation of young people's narratives of identity. Educational Action Research, 20(1), 23-40. https://doi.org/10.1080/09650792.2012.647637

Knight, J., \& Morshidi, S. (2011). The complexities and challenges of regional education hubs: Focus on Malaysia. Higher Education, 62(5), 593-606. doi: 10.1007/s10734-011-9467-2

Korthagen, F. (2017). A foundation for effective teacher education: Teacher education pedagogy based on situated learning. In D. J. Clandinin and J. Husu (Eds.), The Sage handbook of research on teacher education (pp. 528-544). London: Sage.

Korthagen, F., Loughran, J. J., \& Russell, T. (2006). Developing fundamental principles for teacher education programs and practices. Teaching and Teacher Education, 22(8), 1020-1041. https://doi.org/10.1016/j.tate.2006.04.022

Kushner, D. (2002). Game school. Electronic Gaming Monthly, 15, 124. USA: Ziff Davis, Inc.

Lave, J., \& Wenger, E. (1991). Situated learning: Legitimate periperhal participation. London, England: Cambridge University Press.

Loughran, J., Hamilton, M. L., LaBoskey, V. K., \& Russell, T. (2004). International handbook of self-study of teaching and teacher education practices. New York: Springer.

MacMath, S., Sivia, A., \& Britton, V. (2017). Teacher perceptions of project based learning in the secondary classroom. Alberta Journal of Educational Research, 63 (2), 175-192.

Martin, A. K., \& Russell, T. (2009). Seeing teaching as a discipline in the context of preservice teacher education: Insights, confounding issues, and fundamental 
questions. Teachers \& Teaching, 15(2), 319-331. doi: $10.1080 / 13540600902875381$

O’Brien, R. (1998). An overview of the methodological approach of action research. In R. Richardson (Ed.), Theory and practice of action research. Retrieved from http://www.web.ca?-robrien/papers/arfinal.html

Pine, G. J. (2009). Teacher action research: Building knowledge democracies. Thousand Oaks, California: SAGE.

Shute, V. J., \& Kim, Y. J. (2011). Does playing the World of Goo facilitate learning? In D. Y. Dai (Ed.), Design research on learning and thinking in educational settings: Enhancing inteleectual growth and functioning (pp. 359-387). New York, NY: Routledge.

Tomal, D. R. (2010). Action Research for Educators (2nd ed.). Toronto: Rowman \& Littlefield Education.

Vincini, P. (2003). The nature of situated learning. Innovations in learning. Retreived from https://sites.tufts.edu/ets/files/2012/12/newsletter_feb_20031.pdf

Xu, S. J., \& Connelly, F. M. (2009). Narrative inquiry for teacher education and development: Focus on English as a foreign language in China. Teaching and Teacher Education, 25(2), 219-227.

Wolcott, H. F. (1999). Ethnography: A way of seeing. Walnut Creek, CA: AltaMira Press.

Yonemura, M. (1982). Teacher conversations: A potential source for their own professional growth. Curriculum Inquiry, 12(3), 239-256.

Zeichner, K. (2001). Educational action research. In P. Reason \& H. Bradbury (Eds.), Handbook of action research: Participative inquiry \& practice (pp. 273-283). Thousand Oaks, California, SAGE. 


\section{Appendix 1}

Survey Questions - DigiPen Project-Based Learning

\section{Question}

Strongly
Disagree
Disagree Undecided

Agree

Strongly

Agree

1. I had the mathematics skills to complete my program.

1

2

3

4

5

2. I had the computer science skills to complete my program.

1

2

3

4

5

3. I had the physics skills to complete my program.

1

2

3

4

5

4. I have the skills necessary to enter my field of work.

1

2

3

4

5

5. DigiPen helped me learn how to program a computer.

1

2

3

4

5

6. DigiPen helped me learn how to work in a team.

1

2

3

4

5

7. DigiPen gave me greater confidence in my ability to acquire new skills.

1

2

3

4

5

8. DigiPen provided me with leadership skills.

1

2

3

4

5

9. DigiPen helped me develop problem solving skills.

1

2

3

4

5

10. DigiPen helped facilitate my creative thinking.

1

2

3

4

5

11. DigiPen positively affected my post-secondary education.

1

2

3

4

5

12. DigiPen positively affected my career path.

1

2

3

4

5

\section{Open-Ended Questions}

1. Why did you decide to enrol in DigiPen?

2. How did DigiPen affect your learning?

3. How did DigiPen impact your career path?

4. Do you have any other things you'd like to share? 


\section{Appendix 2}

\section{DigiPen Students engaged in Digital Game Design}

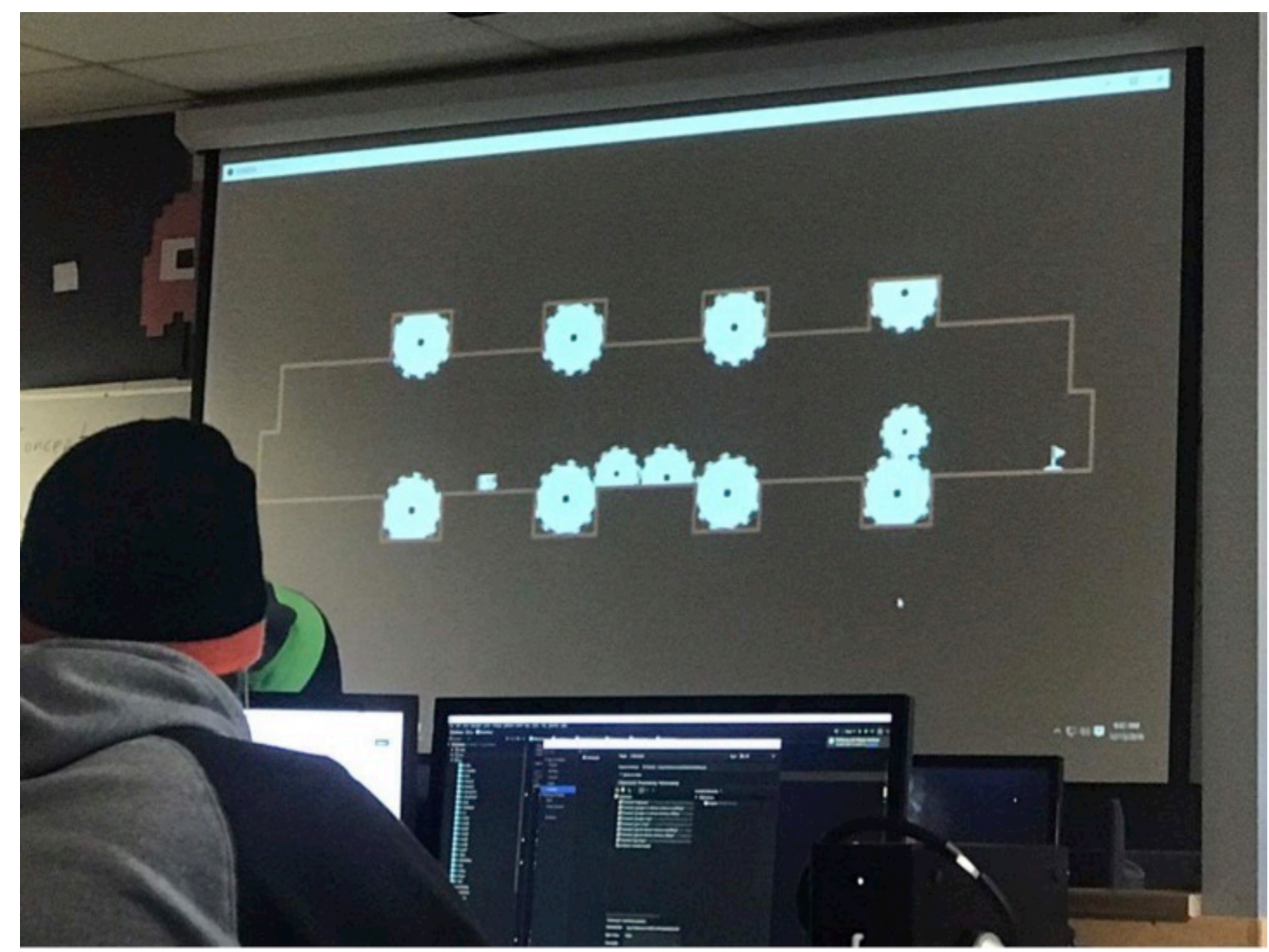

For more photos and videos of this action research, see:

https://www.tru.ca/edsw/research/k-16-research-development-network.html

\section{BIOGRAPHICAL NOTE:}

Edward Howe is Associate Professor and Chair of the School of Education at Thompson Rivers University (TRU) in Kamloops, BC. Prior to coming to TRU in 2014 he worked for more than a decade in Japanese higher education. He obtained his MA in Educational Studies from the University of British Columbia and PhD in Curriculum, Teaching and Learning (Comparative and International Education) from the Ontario Institute for Studies in Education of the University of Toronto. Dr. Howe's main research interests are teacher education and comparative and international education, with a focus on East Asia. His research blends narrative inquiry and reflexive ethnography through "comparative ethnographic narrative" as a means to better understand teacher acculturation and other educational phenomena. Recent publications include internationalization of higher education, transcultural teacher education, and narrative pedagogies. Dr. Howe's teaching focuses on social justice issues, global citizenship education, transformational learning, and educational leadership. 
Andres Ruberg is a Secondary School Instructor in the Kamloops School District. After a brief time in the field of astrophysics he pursued a career in education. During his experiences as an astrophysicist he developed skills in communication, writing proposals and generating computer software to solve unique problems. Since becoming an educator, he has worked steadily to improve his ability to communicate complex concepts to a diverse audience and work as an effective member of a team of professional educators. DigiPen provided the opportunity to run a specialized academy that trains high school students in the fields of programming, digital art and game design with the aim of introducing these students to the video game industry. During his experiences with this academy he has fostered relationships and agreements with postsecondary institutions, modernized the academy curriculum and co-authored research papers based on his current pedagogy. He regularly organizes and runs professional development seminars within the district and teaches at Thompson Rivers University each summer.

\section{ACKNOWLEDGEMENTS:}

Thank you to Thompson Rivers University for funding this research through the Undergraduate Research Education Award Program (2016-2017) and Apprenticeship Fund (2017-2018). We wish to thank the two teacher candidate research assistants, Sara Spada (2016-2017) and Michelle Tondevold (2017-2018) for their significant contributions to this action research project. 